\title{
Flying vs. climbing: Factors controlling arboreal seed removal in oak-beech forests
}

\author{
Ramón Perea, Alfonso San Miguel, Luis Gil* \\ Departamento de Silvopascicultura, ETSI de Montes, Universidad Politécnica de Madrid, Ciudad Universitaria s/n, 28040 Madrid, Spain
}

Keywords:

Seed size

Seed infestation

Foragers density

Removal speed

Fagus sylvatica

Quercus

\begin{abstract}
A B S T R A C T
Nuts are heavy and nutritious seeds that need animals to be successfully dispersed. Most studies address nut removal by a single animal species once seeds fall onto the ground. However, nuts are also accessible before the seed drop and usually to a wide guild of seed foragers. This study examines the factors controlling arboreal seed removal in oak-beech forests within the whole guild of nut foragers. We found that seed-dispersing rodents (Apodemus sylvaticus) were the main acorn removers in the oaks (up to $3.75 \mathrm{~m}$ height), with a rapid seed encounter and a high removal rate. However, rodents did not climb the beech trees, probably due to their smoother bark in comparison to oak bark and/or the lower nutritional value of beechnuts with regard to acorns. Jays (Garrulus glandarius) were more abundant in oak stands (both dense and scattered) and clearly preferred acorns to beechnuts whereas nuthatches (Sitta europaea) were more abundant in beech stands and preferred beechnuts to acorns. Non-storing birds such as great tits (Parus major) also removed acorns and beechnuts, especially in the stands where oaks are dominant. Jays and rodents preferred sound seeds over insect-infested seeds but such a preference was not found for nuthatches. This study highlights that pure beech stands showed a reduced guild of arboreal nut foragers in comparison to oak stands. This different guild could probably affect the spatial patterns of seed dispersal, with a proportionally higher number of long dispersal events for acorns (mostly jay-dispersed) than for beechnuts (mostly nuthatch-dispersed). Long-distance dispersal of beechnuts (by jays) is determined by the presence of other preferred species (oaks) and their frequency of non-mast years. Seed location in different habitats strongly determines the contribution of different arboreal removers (including climbing rodents) and their removal speed, leading to a differential seed fate that will eventually affect tree regeneration. As nuthatches are sedentary birds, it is important to maintain old and dead trees where they can breed (crevices), forage (arthropods) and store seeds in order to favor beechnut dispersal and gene flow. By maintaining or favoring oak trees within beech stands we will ensure a wider guild of arboreal nut dispersers.
\end{abstract}

\section{Introduction}

Seed dispersal is an important component of the tree regeneration process and is the principal ways by which trees move across landscapes (Vander Wall et al., 2005). Nut-producing trees (e.g. Fagaceae) produce abundant and highly nutritious seeds, which are an important food source for many forest vertebrates (Jensen and Nielsen, 1986; Ouden et al., 2005). Nuts are also heavy seeds that need biotic agents (animals) to be dispersed, and, thus, have developed certain traits to attract seed-dispersing animals (Vander Wall, 2001). Genetic parentage analysis also revealed that seedling recruitment in nut-producing trees, such as oaks, occurred at long distances from their mother trees (usually over $50 \mathrm{~m}$ ) as a result of animal seed dispersal (Valbuena-Carabaña et al., 2005). However, some other animals (seed predators) will only consume and destroy the seeds, reducing tree reproduction efficiency (Herrera, 2002).

\footnotetext{
* Corresponding author. Tel.: +34 913367113.

E-mail address: luis.gil@upm.es (L. Gil).
}

Seeds can be removed from the trees (before seed drop) or from the ground (after seed drop or primary dispersal). Many studies have addressed the removal of nuts from the ground (Steele et al., 1993; Gómez et al., 2003; Muñoz et al., 2009; Xiao et al., 2010; Pulido et al., 2010; Perea et al., 2011). However, nuts are also accesible to many foragers when they are still on the mother tree. Following this, a traditional distinction has been made between aerial and terrestrial nut foragers. Among aerial seed foragers, birds are the most prominent guild of nut foragers, which include important scatter-hoarders (e.g. jays) that strongly contribute to seed dispersal (Darley-Hill and Johnson, 1981; Gómez, 2003; Pons and Pausas, 2007a). Among terrestrial, mammals are the main guild of nut foragers with both important seed predators (e.g. ungulates) and potential dispersers (hoarding rodents). However, the contribution of different guilds of animals may differ not only on their foraging ecology (predation vs. dispersal) but on the temporal and spatial scales of their effects and their seed preferences (Hulme and Borelli, 1999). In that way, seed removal has been demonstrated to be determined by the structure of the dominant 
vegetation (Vander Wall, 2001; Hulme and Kollmann, 2005; Perea et al., 2011) due to the fact that some habitats are more suitable for certain foragers (Janzen, 1971; Hulme, 1994). Habitat selection may also determine the proximity of certain seed removers to nut sources, which could eventually affect the probability of nut encounter and the speed at which nuts are removed (Perea et al., unpublished results). In addition, some species of seed foragers are able to discriminate among seeds from different plant species or among intrinsic seed characteristics. Consequently, many seed foragers show preference for certain species over others (Steele et al., 1996; Pons and Pausas, 2007b), mostly in relation to nutritional properties (Wang and Chen, 2008).

Seed quality has shown to be an important trait for many guilds of foragers (e.g. rodents), which clearly preferred large and sound seeds over small and infested seeds (Steele et al., 1996; Muñoz and Bonal, 2008a,b). However, not all foragers show the same preferences for species or have the ability to discriminate some intrinsic seed properties (Cheng and Zhang, 2011; Dixon et al., 1997; Pons and Pausas, 2007b). Thus, different guilds of foragers may contribute differentially to the final seed removal due to dissimilarities in body size, habitat selection, seed preferences or foraging behavior. However, nut removal from the trees have not been fully explored and such factors may be important for seed survival and spatial patterns of dispersal, which will eventually affect tree regeneration.

Although it is widely recognized that small mammals are able to climb the trees (Holisova, 1969; Montgomery, 1980; Štěpánková and Vohralík, 2009), few studies have explored the relative contribution of small mammals to nut removal from the trees (but see Santos and Tellería, 1991; Ida et al., 2004). Seed removal by birds has been demonstrated to play an important role in long distance dispersal (Gómez, 2003; Pons and Pausas, 2007a) whereas small mammals have been considered to be short to medium-distance dispersers (Ouden et al., 2005; Gómez et al., 2008). However, little is known about the role of small mammals as nut removers from the trees, which could compete with avian nut foragers, determining dispersal distances and the eventual seed fate. In addition, no study has yet addressed the foraging decisions of nut-dispersing rodents during the predispersal phase. As a result, it is completely necessary to study the whole guild of nut foragers, including both aerial and climbers, to fully understand the factors controlling the arboreal nut removal and their possible consequences for seed fate and tree recruitment.

The aim of this experimental study was to examine the factors controlling arboreal seed removal in oak-beech forests within the whole guild of nut foragers. We selected oak-beech forest because they are important components of temperate forests in the Northern Hemisphere whose nuts strongly rely on the removal by animals to be effectively dispersed. More specifically, the study goals are: (1) to estimate the relative contribution of different seed foragers to the removal of beechnuts and acorns in the trees; (2) to examine whether seed characteristics (tree-species, seed size and seed infestation) affect seed removal (choice and speed) in the trees; (3) to analyze the influence of different habitats on the relative abundance of each nut forager; (4) to examine whether seed location in different habitats affect the arboreal nut removal along time. Finally, we aim to integrate all these aspects to analyze the consequences of arboreal seed removal (choice and speed) by different nut foragers for the regeneration of oak-beech forests.

\section{Material and methods}

\subsection{Study area}

This study was conducted in a mixed forest with three tree-species: a sub-mediterranean oak (Quercus pyrenaica Willd.), a temperate oak (Quercus petraea Matt. (Liebl.)) and the European beech (Fagus sylvatica L.). The study area is located in the Ayllon mountain range in central Spain $\left(3^{\circ} 30^{\prime} \mathrm{W}, 41^{\circ} 07^{\prime} \mathrm{N}\right.$, Madrid province), at $1400 \mathrm{~m}$ a.s.l., under a submediterranean climate with $958 \mathrm{~mm}$ annual rainfall and a 2-month dry summer. The understory is formed mainly by a few species of evergreen shrubs (Erica arborea, Juniperus communis, Ilex aquifolium, Genista florida and Adenocarpus hispanicus). Different habitats and microhabitats can be found according to plant composition and vegetation structure resulting in a heterogeneous forest (Pardo et al., 2004). Genetic studies in the study area (parentage analysis) revealed that seedling recruitment occurred at long distances from their mother trees (usually over $50 \mathrm{~m}$ ) as a result of animal seed dispersal (ValbuenaCarabaña et al., 2005).

Inside the study area we distinguished three main habitats: (1) Mixed oak stand of Q. pyrenaica and Q. petraea ( 380 stems ha $^{-1}$; basal area of $22.21 \mathrm{~m}^{2} \mathrm{ha}^{-1}$ ) with scattered beech-trees ( 83 stems ha $^{-1}$; $0.79 \mathrm{~m}^{2} \mathrm{ha}^{-1}$ ), containing several shrub species in the understorey (mostly E. arborea and $G$. florida) (2) scattered oak forest of $Q$. pyrenaica and $Q$. petraea (74 stems ha $\mathrm{h}^{-1} ; 2.35 \mathrm{~m}^{2} \mathrm{ha}^{-1}$ ) inserted in a matrix of evergreen shrubs (mainly A. hispanicus and $J$. communis) and (3) pure stand of $F$. sylvatica ( 848 stems ha ${ }^{-1} ; 18.02 \mathrm{~m}^{2} \mathrm{ha}^{-1}$ ) and the surface covered by mostly litter and isolated or small groups of holly trees ( $I$. aquifolium). The tree inventory for each habitat was performed in 2005 (García, 2006). Each habitat was selected in the tree inventory according to their homogeneity in tree composition and structure. In autumn 2008 seed production (including sound and infested seeds) was an average of 74.1 beechnuts $\mathrm{m}^{-2}$ inside the beech forest habitat and 16.7 acorns $\mathrm{m}^{-2}$ (both oak-species included) in the mixed oak habitat. Autumn 2009 showed higher seed production with 105.6 beechnuts $\mathrm{m}^{-2}$ in the beech forest and 67.7 acorns $\mathrm{m}^{-2}$ in the mixed oak habitat (unpublished data).

\subsection{Identification of seed removers}

In order to identify the seed removers, three motion-detection digital video cameras with night vision were used (one for each habitat). Cameras were placed at approximately $2.5-4.0 \mathrm{~m}$ height on a branch of a tree, pointing at a supply tray. The supply tray contained both acorns and beechnuts and was also used for the seed removal experiment (see below). Cameras were rotated every 13-16 days within each habitat and were used in October, November and December, coinciding with the acorn and beechnut ripening period, in 2 years (2008 and 2009).

\subsection{Estimation of seed forager densities}

To estimate rodent abundance we conducted live trapping of small mammals in each habitat on four consecutive days. The trapping period was middle of October 2008 and 2009. Trapping stations were located in each habitat according to a rectangular $5 \times 4$ grid, with $15 \mathrm{~m}$ between stations. Each station had one trap, so that sampling effort was 80 trap-nights per habitat and year. Traps dimensions were $27 \times 7.5 \times 7.5 \mathrm{~cm}$. Bedding was provided (dry leaves) and changed every time an animal was captured. Traps were baited with acorns and sunflower seeds. Captured individuals were identified to species, marked with fur-clipping method and then released at the point of capture (Gurnell and Flowerdew, 2006 ) in the year 2008. Ear-tagging method was used in the year 2009 (National Band and Tag CO. Newport, KY, USA; type 1005-1 for small mammals; approximately $7 \mathrm{~mm}$ length). Permits for live trapping were obtained from the Department of Environment, Regional Government of Madrid (Spain).

To estimate bird abundance we designed a permanent linear transect in each habitat. Transects were $500 \mathrm{~m}$ in length and approximately $50 \mathrm{~m}$ in width (25 $\mathrm{m}$ at each side). Transects were 
performed each month of the seed ripening period (October, November and December) in 2008 and 2009. Bird census started at approximately $9-9.30$ am and we attempted to avoid heavy rain or snow, poor visibility or strong wind conditions. We recorded all the birds we saw and heard following the bird survey instructions from the British Trust for Ornithology (http://www.bto.org).

\subsection{Seed removal experiment}

Each year (2008-2009) we selected four different trees within each habitat ( 12 trees per year). The distance between trees within the same habitat was, at least, $225 \mathrm{~m}$. Tree species were beech for the beech forest habitat and oaks (two Q. pyrenaica and two Q. petraea) for both mixed oak and scattered oak forests. We placed one seed supply tray $(23 \mathrm{~cm}$ diameter) at approximately 2.50 $3.75 \mathrm{~m}$ height on a horizontal branch of each tree (no farther than $1.5 \mathrm{~m}$ from the trunk). Each tray contained 36 seeds with three seeds of the same type. Twelve different types of seeds were considered (three tree species $\times$ two seed sizes $\times$ two infestation conditions). Seeds were marked with a waterproof permanent marker according to the tree-species ( $Q$. pyrenaica, $Q$. petraea and F. sylvatica), seed size (large or small) and infestation conditions (sound vs. insect-infested). Acorns were considered large when the product of seed length $(L)$ and maximum seed width $(W)$ was between 375 and $450 \mathrm{~mm}^{2}$ and small when $120-150 \mathrm{~mm}^{2}$. Beechnuts were considered large when $L * W$ was $120-150 \mathrm{~mm}^{2}$ and small when $L * W$ was $70-100 \mathrm{~mm}^{2}$. Infested acorns were identified by the combination of both emergence hole and oviposit hole of weevil-larvae (Curculio sp., Col.: Curculionidae) and infested beechnuts were identified by a smaller emergence hole of the larvae of Cydia fagiglandana Zeller (Lep.: Tortricidae). Sound acorns were tested by flotation method and only sunken seeds were chosen. All seeds were collected from the study area or in nearby locations during the first fortnight of October 2008 and 2009. The experiment took place during the end of October and throughout November 2008 and 2009, checking every day all the trays during the first 15 days after seed offer. Every day of monitoring we noted the seeds that foragers removed. At the end of the experiment (day 45 ) we revisited the trays and took them out of the branches.

\subsection{Data analysis}

Small mammal abundance was estimated for each habitat according to capture-mark-recapture Schnabel method (Krebs, 1999). Estimation of the density of each bird species was obtained from Burnham et al. (1980) where all existing individuals are assumed to be recorded within the transect limits. To analyze whether there were differences in the density of each seed-foraging species in relation to the habitat we used Linear Mixed Models (LMM) for each species. The response variable was density estimation and the fixed effect was habitat. Year was considered as random effect. We did model checking for normal distribution of residuals, linearity and constant variance. To analyze whether the contribution to seed removal by different seed foragers varied throughout the habitats we built a Generalized Linear Mixed Model with Poisson error family. The response variable was the number of video recordings (count data) and fixed effects were remover species (four factor levels corresponding to each species), habitat (three factor levels), and their interaction. Year was included in the model as random effect. For the two possible models (with or without interaction), the model with the lowest Akaike Information Criterion (AIC) was selected.

To analyze seed removal we used Generalized Linear Mixed Models (GLMM). We built three GLMM, one for each date. Model M1 was run for the first day that foragers encountered the supply stations. Model M2 was built for the 15th day after seed offer and model M3 for the end of the experiment (45th day after seed offer). For all models we took a binary response variable (whether the seed was removed or not). Fixed factors were those that could potentially affect seed removal (tree-species, seed size, infestation conditions, habitat and their possible interactions). Random effects were always those considered in the nested structure (tree nested within habitat and habitat nested within year). For each date, the model always contained the main effects (the studied factors). Only second order interactions were included when reducing the AIC of the model. We tested for overdispersion in all GLMM models. All models were built under R 2.12 .2 software (http://www. r-project.org).

\section{Results}

\subsection{Identification of seed removers}

A total number of 111 video recordings were obtained. Wood mouse (Apodemus sylvaticus) was the main seed remover in the supply trays (Fig. 1), showing significant differences with regard to other foragers (Table 1 ). Five video recordings contained two individuals of Apodemus at the same time (6.5\% of the total number of Apodemus recordings). No significant differences were obtained among bird species in the total number of video recordings $(P>0.179$ for all cases). Lower number of videos were recorded in the beech forest but significant differences were only found for wood mouse (A. sylvaticus) and European jay (Garrulus glandarius), with no recordings in the beech trees (Table 1). No significant interactions were found between the rest of species and habitats $(P>0.569$ for all cases).

\subsection{Estimation of seed forager densities}

A. sylvaticus was the only rodent species captured in the live traps. A total number of 47 captures were obtained. Number of captures showed no significant differences among the habitats $(t=0.48 ; P=0.663)$ and between both years $(t=2.52 ; P=0.253)$. Density estimations of rodents varied from $8.3 \pm 3.8$ to $13.3 \pm 5.2$ individuals $\mathrm{ha}^{-1}$

Mixed oak forest contained the highest density estimation of avian seed foragers, with significant differences in comparison to beech forest $(t=-2.90 ; P=0.006)$ and scattered oak forest $(t=-2.11 ; P=0.041 ;$ Fig. 2$)$. However, each bird species showed a significant higher or lower density in a particular habitat. Thus, the Eurasian nuthatch (Sitta europaea) showed a significantly higher density in the beech habitat with regard to mixed oak forest

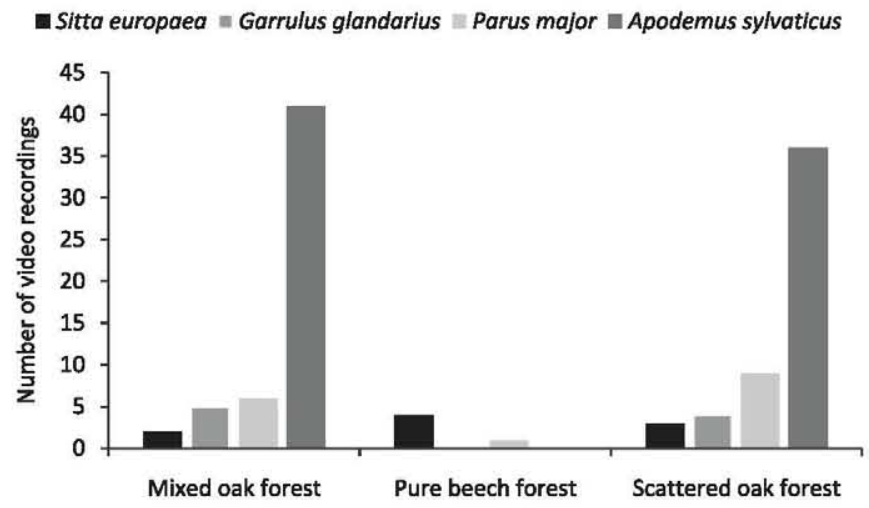

Fig. 1. Number of video recordings with animals removing acorns/beechnuts in the trees for different habitats within an oak-beech forest in Central Spain. Sitto europaea, Garrulus glandarius and Parus major are bird species whereas Apodemus sylvaticus is a rodent species. 
Table 1

Summary of the mixed model to analyze the number of video recordings in relation to habitat and remover species. $N$ refers to the number of video recordings, $\%$ is the percentage of video recordings for each species or habitat relative to the total number of video recordings, $Z$ is the $Z$-score for normal distribution and $P$ the statistical level (referred to the first factor level).

\begin{tabular}{|c|c|c|c|c|c|}
\hline & & $N$ & $\%$ & $Z$ & $P$ \\
\hline \multirow[t]{4}{*}{ Seed remover } & Sitta europaea & 9 & 8.1 & - & - \\
\hline & Garrulus glandarius & 9 & 8.1 & 1.09 & 0.274 \\
\hline & Parus major & 16 & 14.4 & 1.34 & 0.179 \\
\hline & Apodemus sylvaticus & 77 & 69.4 & 4.66 & $<0.001$ \\
\hline \multirow[t]{3}{*}{ Habitat } & Mixed oak forest & 54 & 48.7 & - & - \\
\hline & Beech forest & 5 & 4.5 & 0.80 & 0.424 \\
\hline & Scattered oak forest & 52 & 46.8 & 0.44 & 0.657 \\
\hline \multirow[t]{6}{*}{ Interactions } & $\begin{array}{l}\text { Mixed oak forest: } \\
\text { Apodemus sylvaticus }\end{array}$ & 41 & 36.9 & - & - \\
\hline & $\begin{array}{l}\text { Beech forest: Apodemus } \\
\text { sylvaticus }\end{array}$ & $\mathbf{0}$ & 0.0 & -3.29 & 0.001 \\
\hline & $\begin{array}{l}\text { Scattered oak forest: } \\
\text { Apodemus sylvaticus }\end{array}$ & 36 & 32.4 & -0.57 & 0.569 \\
\hline & $\begin{array}{l}\text { Mixed oak forest: } \\
\text { Garrulus glandarius }\end{array}$ & 5 & 55.5 & - & - \\
\hline & $\begin{array}{l}\text { Beech forest: } \\
\text { Garrulus glandarius }\end{array}$ & $\mathbf{0}$ & 0.0 & -2.05 & 0.040 \\
\hline & $\begin{array}{l}\text { Scattered oak forest: } \\
\text { Garrulus glandarius }\end{array}$ & 4 & 45.5 & -0.55 & 0.555 \\
\hline
\end{tabular}

$\mathrm{AIC}=36.65$; Dispersion $=0.46$; bold type indicates statistical significance $(P<0.05)$.

들 2008

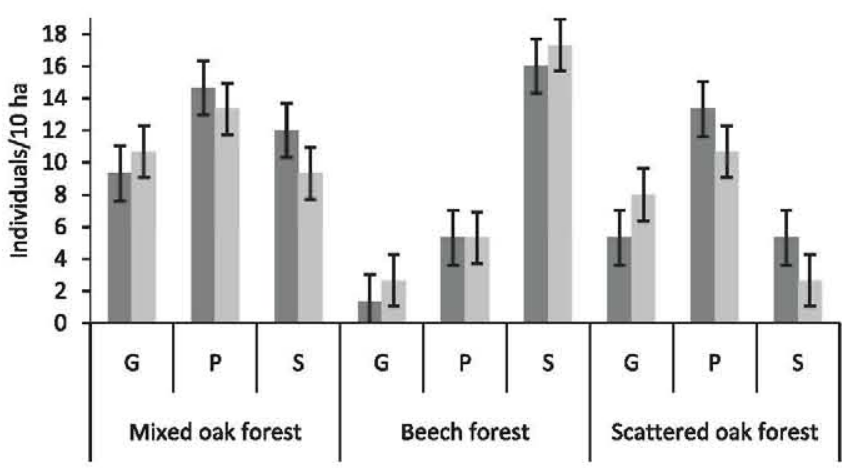

Fig. 2. Density estimations of avian nut removers for each habitat and autumn. Estimations were obtained as a mean of the monthly bird census for each autumn (October-December). $\mathrm{G}=$ Garrulus glandarius; $\mathrm{P}=$ Parus major; $\mathrm{S}=$ Sitta europaea .

$(t=2.88 ; P=0.012)$ and scattered oak forest $(t=-5.27 ; P<0.001)$. No significant differences were found between mixed oak forest and scattered oak forest $(t=-2.09 ; P=0.054)$ for $S$. europaea. Significantly higher density of $G$. glandarius was found in the mixed oak habitat in comparison to the beech forest $(t=-3.27$; $P=0.006$ ) but no significant differences were found between mixed oak and scattered oak forests $(t=-2.08 ; P=0.056)$. Density estimation of great tit (Parus major) was significantly lower in the beech forest (Fig. 2) with regard to mixed oak forest ( $t=-2.89$; $P=0.012)$ and scattered oak forest $(t=-2.36 ; P=0.043)$ but no differences were found between mixed oak and scattered oak forests $(t=-0.72 ; P=0.482)$.

\subsection{Seed removal}

Foragers removed an average of $30.2 \pm 23.7 \%$ of the total number of seeds on the first day that they encountered the supply trays. Time to encounter the trays was higher in the pure beech forest ( $8.6 \pm 3.3$ days) in comparison to mixed oak-beech forest $(3.2 \pm 2.5$ days $)$ and scattered oak forest ( $3.3 \pm 1.2$ days $)$. Seed removal on the first day was significantly affected by the habitat (Table 2) with more seeds removed in the mixed oak forest and very low removal in the beech forest (Fig. 3). Seed removal was significantly higher for sound seeds than for insect-infested seeds (Table 2). However, no significant preference for larger seeds was found (Table 2). For all habitats, no differences were found in the removal of both Quercus species. Proportion of beechnut removal differed among habitats. In the beech forest, a significantly higher proportion of beechnuts was removed in comparison to both mixed and scattered oak forests (Fig. 3 and Table 2). Both infested and small seeds were removed significantly less frequently in the scattered oak forest than in both mixed oak forest and beech forest $(P<0.018$ for all comparisons; Table 2$)$.

Removal after 15 days of seed offer revealed that significantly lower number of seeds were removed in the beech forest (36.1\%) in comparison to the other habitats $(72.2 \%$ for mixed oak forest and $98.1 \%$ for scattered oak forest; $P<0.001$ for both comparisons; Table 2). However, a significantly higher proportion of beechnuts was removed in the beech forest (beechnuts accounted for $84.2 \%$ of the total removal) with regard to mixed oak forest (37.2\%) and scattered oak forest (33.0\%). Seed infestation and seed size did not affect the removal after 15 days and no other significant interactions between factors were found (Table 2). For the last day of the experiment (45th day), we obtained the same effects as on the 15 th day (Table 2). All the seeds were removed in the scattered oak forest as opposed to beech forest where only $62.0 \%$ of seeds were eventually removed $(97.2 \%$ of beechnut removal and $44.4 \%$ of acorn removal). Mixed oak forest showed $82.4 \%$ of removal at the end of the experiment ( $88.9 \%$ of beechnut removal and $79.2 \%$ of acorn removal).

\section{Discussion}

Results from the video recordings showed that both birds and rodents are important nut removers from the trees. Surprisingly, we obtained that $A$. sylvaticus was the main nut remover in the oak-trees, revealing that they can be important arboreal acorn removers, at least up to $3.75 \mathrm{~m}$ height. These findings should be taken with caution since we could not address whether rodents would be able to remove seeds from higher branches and, thus, we may be overestimating the relative contribution of rodents to predispersal nut removal. Santos and Tellería (1991) also found that wood mice can remove acorns from holm-oaks (Quercus ilex) but they highlighted that rodents did not walk distances farther than $3.5 \mathrm{~m}$ from the base of the trunk. However, other studies have found evidence of arboreal activity of $A$. sylvaticus up to $5 \mathrm{~m}$ height (Sarà, 2008) and other Apodemus species have been found at $19 \mathrm{~m}$ above ground (Ida et al., 2004) or up to $23 \mathrm{~m}$ for Apodemus flavicollis (Borowski, 1963). Moreover, Tattersall and Whitbread (1994) found that $20 \%$ of wood mice captures are above the ground, which indicates that arboreal activity of A. sylvaticus is quite extensive. However, we found no evidence of arboreal nut removal by wood mice (neither videos nor feces) in the beech trees, despite rodent density was similar among all habitats. We suggest two possible non-exclusive explanations: (1) beech bark is considerably less rougher than oak bark and more difficulties (higher energy cost) would exist for wood mice to climb, due to their morphological constraints in their arboreal ability (Santos and Tellería, 1991); (2) beechnuts are less profitable seeds than acorns and, thus, rodents would have a lower energy intake when climbing the beech trees in comparison to oak trees.

This study also adds that wood mice are the first species in encountering the nuts (in oak trees) and, thus, remove most of the seeds they select during the first night. It took longer for birds to encounter the seeds, at least when they are located in low branches (below $3.75 \mathrm{~m}$ height). In addition, birds seem to remove 
Table 2

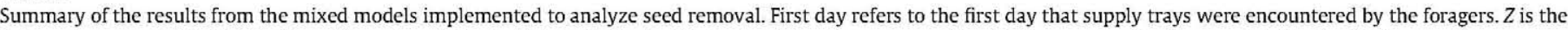
Z-score for normal distribution (negative values indicate that seeds for that factor level have been proportionally less removed with regard to the first factor level).

\begin{tabular}{|c|c|c|c|c|c|c|c|}
\hline & & \multicolumn{2}{|c|}{ M1. First day } & \multicolumn{2}{|c|}{ M2. Day 15} & \multicolumn{2}{|c|}{ M3. Day 45} \\
\hline & & $Z$ & $P$ & $Z$ & $P$ & $Z$ & $P$ \\
\hline Tree-species & $\begin{array}{l}\text { Q. petraea acorns } \\
\text { Q. pyrenaica acorns } \\
\text { F. sylvatica beechnuts }\end{array}$ & $\begin{array}{l}- \\
-0.76 \\
-0.25\end{array}$ & $\begin{array}{l}- \\
0.447 \\
0.801\end{array}$ & $\begin{array}{r}- \\
-0.27 \\
1.14\end{array}$ & $\begin{array}{l}- \\
0.789 \\
0.256\end{array}$ & $\begin{array}{r}- \\
-1.02 \\
0.72\end{array}$ & $\begin{array}{l}- \\
0.307 \\
0.471\end{array}$ \\
\hline Seed infestation & $\begin{array}{l}\text { Sound } \\
\text { Insect-infested }\end{array}$ & $-\overline{2.02}$ & $\overline{0.043}$ & $\begin{array}{l}- \\
-1.95\end{array}$ & - & -1.42 & - \\
\hline Seed size & $\begin{array}{l}\text { Large } \\
\text { Small }\end{array}$ & $-\overline{1.53}$ & $\overline{0} 126$ & $\overline{1.26}$ & $\overline{0 .} 209$ & $-\overline{1.36}$ & $\overline{0} .175$ \\
\hline Habitat & $\begin{array}{l}\text { Mixed oak forest } \\
\text { Beech forest } \\
\text { Scattered oak forest }\end{array}$ & $\begin{array}{l}- \\
-3.29 \\
-2.57\end{array}$ & $\begin{array}{r}- \\
<0.001 \\
0.010\end{array}$ & $\begin{array}{r}- \\
-4.57 \\
0.01\end{array}$ & $\begin{array}{r}- \\
<0.001 \\
0.991\end{array}$ & $\begin{array}{r}- \\
-2.76 \\
0.01\end{array}$ & $\begin{array}{l}- \\
\mathbf{0 . 0 0 6} \\
0.995\end{array}$ \\
\hline Interactions & $\begin{array}{l}\text { Beechnuts: Mixed oak forest } \\
\text { Beechnuts: Beech forest } \\
\text { Beechnuts: Scattered oak forest } \\
\text { Infested seeds: Mixed oak forest } \\
\text { Infested seeds: Beech forest } \\
\text { Infested seeds: Scattered oak forest } \\
\text { Small seeds: Mixed oak forest } \\
\text { Small seeds: Beech forest } \\
\text { Small seeds: Scattered oak forest }\end{array}$ & $\begin{array}{l}- \\
2.57 \\
-2.94 \\
- \\
1.34 \\
-2.36 \\
- \\
0.29 \\
-2.47\end{array}$ & $\begin{array}{l}- \\
\mathbf{0 . 0 1 0} \\
\mathbf{0 . 0 0 3} \\
- \\
0.182 \\
\mathbf{0 . 0 1 8} \\
- \\
0.767 \\
\mathbf{0 . 0 1 3}\end{array}$ & $\begin{array}{l}\overline{3.81} \\
-0.01 \\
\text { Not found }\end{array}$ & $\begin{array}{r}- \\
<\mathbf{0 . 0 0 1} \\
0.993\end{array}$ & $\begin{array}{l}\overline{\mathbf{2 . 3 9}} \\
-0.009 \\
\text { Not found }\end{array}$ & $\begin{array}{l}\overline{\mathbf{0 . 0 1 7}} \\
0.999\end{array}$ \\
\hline
\end{tabular}

M1: $\mathrm{AIC}=290.8 ;$ Dispersion $=0.89 ; \mathrm{M} 2: \mathrm{AIC}=226.6 ;$ Dispersion $=1.01 ; \mathrm{M} 3: \mathrm{AIC}=222.3 ;$ Dispersion $=0.80$.

Bold type indicates statistical significance $(P<0.05)$.

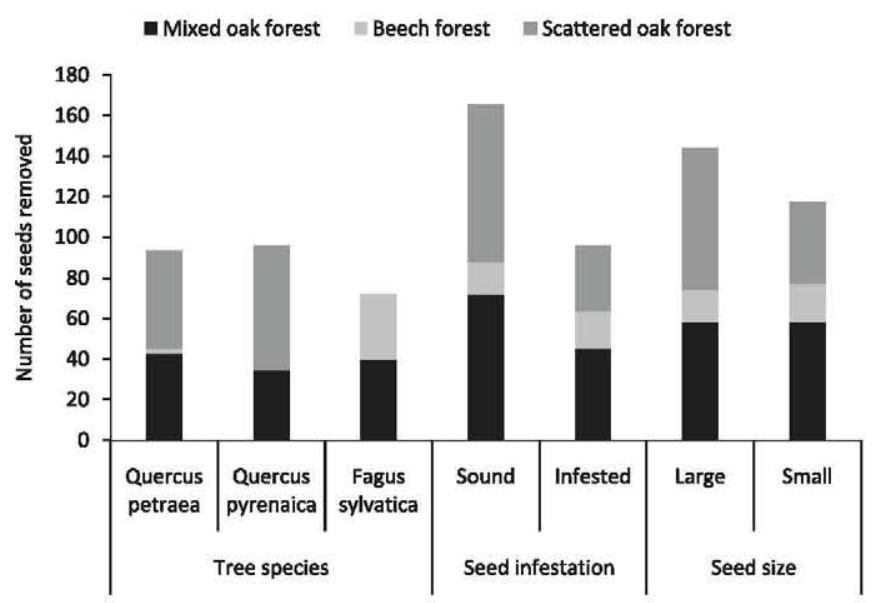

Fig. 3. Seed selection by arboreal foragers for each habitat according to treespecies, seed infestation and seed size. Seed selection was obtained from the seed removal on the first day that foragers encountered the supply stations (when al seeds were available).

the seeds at lower rates (less number of seeds per day). However, we could not assess whether the same individual was removing the seeds (only $6.5 \%$ videos contained two individuals of Apodemus), which would help us to elucidate the origin of the high removal rate by rodents (high rodent density vs. high individual activity). Notwithstanding, rodent densities were much higher (from 83 to 133 individuals per $10 \mathrm{ha}$ ) compared with those of avian seed foragers (from 21 to 32 individuals per 10 ha for all bird species), which could explain the rapid seed encounter for rodents. These findings show a possible strong competition for acorns between arboreal rodents and birds, which could have implications for the spatial patterns of acorn dispersal.

Regarding beechnuts, we found that they were only removed by birds, mainly $S$. europaea, followed by $P$. major. Surprisingly, no seeds were removed by $G$. glandarius in the beech forest, probably due to their lower density (Fig. 2) and their preference for acorns in agreement with Bossema (1979) and Nilsson (1985). Thus, jays mainly forage in habitats where they can potentially find their preferred food items. This would explain why even acorns that were placed in the beech trees went unnoticed by jays. In addition, a higher proportion of beechnut removal was found only in the beech forest, precisely where rodents and jays removed no seeds, which reveals that small passerines ( $S$. europaea and $P$. major) clearly prefer beechnuts, probably because they can transport them more easily than acorns. This, together with the fact that nuthatches have been found at higher densities in the beech forest in comparison to other nut foragers, indicates that S. europaea is the main beechnut remover from the trees. Although studies about S. europaea in Europe show that breeding populations are generally higher in oak forests than in beech forests (Matthysen and Quinn, 1998) we suggest that in mixed oak-beech forest, during autumn, nuthatches use beech stands more frequently than oak stands due to their higher preference for beechnuts and the lack of competition with other nut foragers (jays and rodents). Thus, pure beech stands showed a reduced guild of arboreal nut foragers in comparison to oak stands. This different guild could explain the dissimilarities found in acorn and beechnut removal, which probably affect the spatial patterns of seed dispersal. Nuthatches have smaller territory sizes than jays and, therefore, shorter movements (Matthysen, 1989; Rolando, 1998). Furthermore, jays are commonly found at forest edges and in scattered oak forests with long-distance movements among patches (Bossema, 1979; Gómez, 2003; Ouden et al., 2005), whereas nuthatches usually remain in large forested patches (Matthysen and Currie, 1996) and hoard the seeds close to the supply source, usually less than $40 \mathrm{~m}$ (Moreno et al., 1981). These behavioral patterns could vary considerably the seed shadow of acorns and beechnuts, since maximum dispersal distances would be potentially longer for acorns (mostly jay-dispersed) than for beechnuts (mostly nuthatch-dispersed).

On the other hand, beechnuts will have higher probability of being dispersed to long distances when acorns are not available for jays since jays will then shift to remove beechnuts (Nilsson, 1985). As a result, beechnuts would potentially increase their long-dispersal events in mixed oak-beech forests only in years with low acorn production. This study reveals that long-distance dispersal of beechnuts (by jays) should take into account the presence of other preferred species (oaks) and their frequency of 
non-mast years. Thus, nut-producing trees compete for long-distance dispersers, which might have important consequences for the spread rate of some favored fagaceous species (with preferred seeds or frequent mast years) over others (less preferred or sporadic mast years).

Nut foragers were able to discriminate seed infestation, preferring sound seeds to infested, in line with other studies about jays (Dixon et al., 1997) and rodents (Muñoz and Bonal, 2008b). Hence, sound seeds would have higher probability of being dispersed and they would be more likely to become established because sound seeds contain higher cotyledon mass (higher energy content). However, seed size was not a relevant characteristic in the seed choice because once the supply station was found, foragers removed most of the small and large seeds on the same day and no significant differences were obtained. Besides, the wide range of body sizes for the whole guild make foragers overlap in their seed size preferences. Thus, in the scattered-oak forest, where seed removal was slower on the first day, we found that both small and infested seeds were proportionally less removed than in mixed oak forest, where more seeds were removed on the first day. However, after 15 days of monitoring removal, differences in seed removal between mixed oak and scattered oak forest become non-significant. This reveals that after 15 days of continuous seed removal, differences in seed selection become shorter and even insect-infested seeds are eventually removed. It is also surprising that, only in pure beech stands, infested beechnuts showed higher percentage of removal compared to sound beechnuts (although no significant), which suggest that nuthatches may not be able to discriminate between sound and infested beechnuts or that nuthatches, which strongly feed on arthropods (Obeso, 1988), would be also interested in infested beechnuts. Further studies in foraging decisions of small passerines are needed to obtain conclusive results.

Finally, differences in the foraging behavior and habitat selection of the studied species reveal important implications for forest regeneration and management. Jays and wood mice are known as scatter-hoarders and cache most of the acorns individually under the ground surface (Pons and Pausas, 2007a; Perea et al., 2011), which decreases seed predation by ungulates and seed desiccation (Perea et al., 2011). Favoring arboreal seed removal in oaks, which is mainly performed by potential dispersers (jays and rodents), will reduce seed removal on the ground, which is commonly performed by seed predators such as ungulates, limiting natural regeneration (Pulido and Díaz, 2005; Muñoz et al., 2009). Furthermore, shrub cover will increase wood mice activity and will ensure rodent presence (Ouden et al., 2005) and, thus, will increase the occurrence of arboreal seed removal by rodents. Regarding beech regeneration, nuthatches are known to store the seeds mostly in bark crevices of trunks and thick branches with few caches below ground (Moreno et al., 1981; Källander, 1993). However, nuthatches also contribute to dispersal by dropping the seeds inadvertently, especially when seeds are too heavy to transport them or when extracting them from the hoards located in the trees (Perea, pers. obs.). As nuthatches are sedentary birds, it is important to maintain old and dead trees where they can breed (crevices), forage (arthropods) and store seeds in order to favor beechnut dispersal and gene flow. By maintaining or favoring oak trees within beech forests we will ensure a wider guild of arboreal nut dispersers and higher population of nuthatches, which prefer oak bark to forage and breed (Matthysen and Quinn, 1998). However, great tits are known as non-storing birds (Sherry, 1989) and, thus, they mostly act as seed predators. Placement of nest boxes is a recommended measure in stands lacking of natural cavities to encourage populations of hole-nesting birds such as nuthatches and great tits. In order to favor nuthatches populations over those of great tits, nest boxes should be located higher up in the trees where nuthatches occupy proportionally more nests than great tits (Nilsson, 1985) and with
$32 \mathrm{~mm}$ diameter entrance hole (instead of $28 \mathrm{~mm}$ for great tits) according to the Royal Society of the Protection of Birds (http:// www.rspb.org.uk).

\section{Acknowledgments}

We would like to thank Jesús Alonso and Irene Moreno for their assistance in field and laboratory work. Ramón Perea is supported by a Ph.D. grant from Universidad Politécnica de Madrid. This study was funded by the Comunidad Autónoma de Madrid (Consejería de Medio Ambiente, Vivienda y Ordenación del Territorio) and the projects REGENFOR-CM S2009AMB-1668 (Comunidad de Madrid) and AGL2006-00813 of the Spanish CICYT.

\section{References}

Borowski, S., 1963. Apodemus flavicollis (Melchior, 1834) in the tops of tall trees. Acta Theriol. 6, 314.

Bossema, 1., 1979. Jays and oaks: an eco-ethological study of a symbiosis. Behaviour $1,117$.

Burnham, K.P., Anderson, D.R., Laake, J.L., 1980. Estimation of density from line transect sampling of biological populations. Wildl. Monogr. 72, 3-202.

Cheng, J., Zhang, H., 2011. Seed-hoarding Edward's long-tailed rats Leopoldamys edwardsi in response to weevil infestation in cork oak Quercus variabilis. Curr. Zool. 57, 50-55.

Darley-Hill, S., Johnson, W.C., 1981. Acorn dispersal by the blue jay (Cyanocitta cristata). Oecologia 50, 231-232.

Dixon, M.D., Johnson, W.C., Adkisson, C.S., 1997. Effects of weevil larvae on acorn use by blue jays. Oecologia 111, 201-208.

García, A., 2006. Dinámica forestal del Hayedo de Montejo en la última década mediante comparación de dos inventarios sucesivos. EUIT Forestal. Universidad Politécnica de Madrid, Madrid.

Gómez, J.M., 2003. Spatial patterns in long-distance dispersal of Ouercus ilex acorns by jays in a heterogeneous landscape. Ecography 26, 573-584.

Gómez, J.M., García, D., Zamora, R., 2003. Impact of vertebrate acorn- and seedlingpredators on a Mediterranean Quercus pyrenaica forest. For. Ecol. Manage. 180, 125-134.

Gómez, J.M., Puerta-Piñero, C., Schupp, E.W., 2008. Effectiveness of rodents as loca seed dispersers of Holm oaks. Oecologia 155, 529-537.

Gurnell, J., Flowerdew, J.R., 2006. Live Trapping Small Mammals; A Practical Guide, fourth ed. Mammal Society Occasional Publications, London.

Herrera, C.M., 2002. Seed dispersal by vertebrates. In: Herrera, C.M., Pellmyr, o. (Eds.), Plant-Animal Interactions. An Evolutionary Approach. Blackwell Science, Oxford, pp. $185-208$

Holisova, V., 1969. Vertical movements of some small mammals in a forest. Zool Listy $18,121-141$.

Hulme, P.E., 1994. Postdispersal seed predation in grassland - its magnitude and sources of variation. J. Ecol. 82, 645-652.

Hulme, P.E., Borelli, T., 1999. Variability in post-dispersal seed predation in deciduous woodland: relative importance of location, seed species, burial and density. Plant Ecol. 145, 149-156.

Hulme, P.E., Kollmann, J., 2005. Seed predator guilds, spatial variation in postdispersal seed predation and potential effects on plant demography. In: Forget, P.M., Lambert, J., Vander Wall, S.B. (Eds.), Seed Fate. CABI Publishing, Wallingford, pp. 9-30.

Ida, H., Hotta, M., Ezaki, Y., 2004. Predispersal predation by rodents to beechnuts (Fagus crenata Blume). Ecol. Res. 19, 503-509.

Janzen, D.H., 1971. Seed predation by animals. Annu. Rev. Ecol. Syst. 2, 465-492

Jensen, T.S., Nielsen, O.F., 1986. Rodents as seed dispersers in a heath-oak wood succession. Oecologia 70, 214-221.

Källander, H., 1993. Food caching in the European nuthatch Sitta europaea. Ornis Svec. 3, 49-58.

Krebs, C.J., 1999. Ecological Methodology, second ed. Addison-Wesley Educationa Publishers, New York, USA

Matthysen, E., 1989. Nuthatch Sitta europaea demography, beech mast, and territoriality. Ornis Scand. 20, 278-282.

Matthysen, E., Currie, D., 1996. Habitat fragmentation reduces disperser success in juvenile nuthatches Sitta europaea: evidence from patterns of territory establishment. Ecography 19, 67-72.

Matthysen, E., Quinn, D., 1998. The Nuthatches. T \& AD Poyser, London.

Montgomery, W.I., 1980. The use of arboreal runways by the woodland rodents, Apodemus sylvaticus (L.), A. flavicollis (Melchior) and Clethrionomys glareolus (Schreber). Mamm. Rev. 10, 189-195.

Moreno, J., Lundberg, A., Carlson, A., 1981. Hoarding of individual nuthatches Sitto europoea and march tits Parus polustris. Ecography 4, 263-269.

Muñoz, A., Bonal, R., 2008a. Are you strong enough to carry that seed? Seed size body size ratios influence seed choices by rodents. Anim. Behav. 76, 709-715.

Muñoz, A., Bonal, R., 2008b. Seed choice by rodents: learning or inheritance? Behav. Ecol. Sociobiol. 62, 913-922.

Muñoz, A., Bonal, R., Diaz, M., 2009. Ungulates, rodents, shrubs: interactions in a diverse Mediterranean ecosystem. Basic Appl. Ecol. 10, 151-160. 
Nilsson, S.G., 1985. Ecological and evolutionary interactions between reproduction of beech Fagus sylvatica and seed eating animals. Oikos 44, 157-164.

Obeso, J.R., 1988. Alimentación de Sitta europaea en pinares de la sierra de Cazorla SE España, durante el verano y el otoño. Ardeola 35, 45-50.

Ouden, J., Jansen, P.A., Smit, R., Forget, P.M., Lambert, J.E., Hulme, P.E., Vander Wall, S.B., 2005. Jays, mice and oaks: predation and dispersal of Quercus robur and $Q$. petraea in North-western Europe. In: Forget, P.M., Lambert, J., Vander Wall, S.B. (Eds.), Seed Fate: Predation, Dispersal and Seedling Establishment. CAB Publishing, Wallingford, pp. 223-240.

Pardo, F., Gil, L., Pardos, J.A., 2004. Structure and composition of pole-stage stands developed in an ancient wood pasture in central Spain. Forestry $77,67-74$

Perea, R., San Miguel, A., Gil, L., 2011. Leftovers in seed dispersal: ecologica implications of partial seed consumption for oak regeneration. J. Ecol. 99, 194-201.

Pons, J., Pausas, J.G., 2007a. Acorn dispersal estimated by radio-tracking. Oecologia $153,903-911$

Pons, J., Pausas, J.G., 2007b. Not only size matters: acorn selection by the European jay (Garrulus glandarius). Acta Oecol. 31, 353-360.

Pulido, F.J., Díaz, M., 2005. Regeneration of a Mediterranean oak: a whole-cycle approach. Ecoscience 12, 92-102.

Pulido, F., García, E., Obrador, J.J., Moreno, G., 2010. Multiple pathways for tree regeneration in anthropogenic savannas: incorporating biotic and abiotic drivers into management schemes. J. Appl. Ecol. 47, 1272-1281.

Rolando, A., 1998. Factors affecting movements and home ranges in the jay (Garrulus glandarius). J. Zool. 246, 249-257.

Santos, T., Tellería, J.L., 1991. An experiment to test the consumption of arboreal food by wood mouse Apodemus sylvaticus. Z. Säugetierkd. 56, 19-24.

Sarà, M., 2008. The use of artificial nest-boxes by Apodemus sylvaticus dichrurus in Sicily. Folia Zool. 57, 294-299.
Sherry, D.F., 1989. Food storing in the Paridae. The Wilson Bull. 101, 289-304.

Steele, M.A., HadjChikh, L.Z., Hazeltine, J., 1996. Caching and feeding decisions by Sciurus carolinensis: responses to weevil-infested acorns. J. Mammal. 77, 305-314.

Steele, M.A., Knowles, T., Bridle, K., Simms, E.L., 1993. Tannins and partial consumption of acorns - implications for dispersal of oaks by seed predators. Am. Midl. Nat. 130, 229-238.

Štěpánková, J., Vohralîk, V., 2009. Vertical activity of the yellow-necked mouse (Rodentia: Muridae) at edge of a mixed forest. Folia Zool. 58, 26-35.

Tattersall, F., Whitbread, S., 1994. A trap-based comparison of the use of arboreal vegetation by populations of bank vole (Clethrionomys glareolus), woodmouse (Apodemus sylvaticus) and common dormouse (Muscardimus avellanarius). ]. Zool. 233, 309-314.

Valbuena-Carabaña, M., González-Martínez, S.C., Sork, V.L., Collada, C., Soto, A., Goicoechea, P.G., Gil, L., 2005. Gene flow and hybridisation in a mixed oak forest (Quercus pyrenaica willd and Quercus petraea (matts.) liebl. in Central Spain. Heredity $95,457-465$.

Vander Wall, S.B., 2001. The evolutionary ecology of nut dispersal. Bot. Rev. 67, 74-117.

Vander Wall, S.B., Kuhn, K.M., Beck, M.J., 2005. Seed removal, seed predation, and secondary dispersal. Ecology $86,801-806$.

Wang, B., Chen, J., 2008. Tannin concentration enhances seed caching by scatterhoarding rodents: an experiment using artificial seeds. Acta Oecol. 34, 379-385.

Xiao, Z.S., Gao, X., Steele, M.A., Zhang, Z.B., 2010. Frequency-dependent selection by tree squirrels: adaptive escape of nondormant white oaks. Behav. Ecol. 21 169-175. 